\title{
Diabetic Wound Management- A Therapeutic Challenge
}

\author{
Satarupa Sarkar ${ }^{1 *}$ and Minnu K Francis ${ }^{2}$ \\ ${ }^{1}$ Indian Institute of Technology, India \\ ${ }^{2}$ Rajah Muthiah Dental College \& Hospital, India \\ Submission: May 26, 2018; Published: May 22, 2018 \\ *Corresponding author: Satarupa Sarkar, Indian Institute of Technology, Kharagpur, India, Email: satarupa@iitkgp.ac.in
}

\section{Introduction}

The health burden of diabetes is rising across the wideranging ethnic groups and at all socio-economic levels, fuelled by alarming escalation of lifestyle changes and obesity [1]. The latest epidemiology indicates the prevalence of 382 million diabetics in 2013, anticipated to increase to 592 million by 2035 with maximum surge of cases in India. This dramatic worldwide expansion of diabetes prevalence has given rise to various diabetes-related complications [2].

According to the Centers for Disease Control, diabetics during their lifetime have a 15\%-25\% risk of developing an ulcer with a frequency rate as high as $50 \%-70 \%$ over the ensuing 5 years. More than $85 \%$ of major amputations in diabetic patients begins as foot ulceration as a complication and $50 \%$ of patients within 5 years of amputation, either die or suffer from contralateral limb loss [3]. Chronic diabetic wound is the most common cause of hospitalization among complications of diabetes. Multifaceted system pathology makes treatment of diabetic wound quite recalcitrant due to obvious association of cellular and molecular oddity. The early diagnosis and management may avert further problems, associated morbidity and mortality [4].

The persuasive mechanisms behind the deviation of wound healing from normal events include halt in a pathologic state of inflammation associated with disturbed neovascularization, reduced collagen synthesis, alterations in collagen morphology, disordered connective tissue metabolism, increased proteolytic activity, defective macrophage role, decreased growth factor production and quantity of granulation tissue [5]. Oxidative stress generated by reactive oxygen species (ROS) also plays a substantial role in diabetes initiating poor healing of wound [6]. A critical stimulus for diabetic wound healing is precise arrangement of collagen fibrils into ordered assembly with optimized post translational modification. According to glycation hypothesis, hyperglycemia may cause complications through increased glycation [7] which leads to abnormalities in turnover rate, receptor recognition, enzyme activity and physicochemical properties of the wide variety of proteins and that over time these abnormalities sufficiently predispose to disease development [8]. Similarly during the course of diabetes, the collagen fibers encounter various physicochemical changes including a reduced flexibility, considerable resistance to enzymatic digestion, altered ligand binding activity and other suprastructural adjustments. As normal collagen cross linking is a prerequisite to stabilize fibrils and provide distensibility, elasticity and mechanical strength, uncontrolled cross-links formed in diabetic collagen may have significant damaging effects [9].

There is an urgent medical need to understand the underlying structural and functional abnormalities through which diabetes damages wound healing. To improve the current unsatisfactory clinical outcomes and to ameliorate the prognosis and the quality of life of patients with worsened healing ability, future therapies will probably have to target the multi factorial aspects of diabetic wound chronicity. Currently, single growth factor supplementation (PDGF) administered topically to the wound is the only FDA approved therapy for diabetic wound and has been met with only modest success. Additionally, clinical trials with other growth factors have showed variable success rates, suggesting the need for better modulation of the wound environment [10]. Many of the synthetic drugs used for treatment of wounds are not affordable because of their high cost. In the developing countries, some novel and effective techniques, such as tissue-engineered wound dressings or recombinant growth factors are not accessible for majority of the patients and are uneconomical too. Also, diabetic wound patients require prolonged periods of dressings and this causes a significant financial tribulation to the health-care system. Nowadays, compared to synthetic medicines, traditional and herbal therapy is attaining acceptance as a consequence of its outspread availability, moderate efficacy, no or fewer side effects and low cost [11]. From primeval times the legacy of honey which is a natural product habitually known as collection of nectars processed by honey bees has continued in traditional medicine and notably in the treatment of wound healing [12]. With 
perpetual technological improvement, the information regarding honey's excellent wound healing capacity has accumulated at a rapid pace. Further research studies comparing honey with standard wound management therapies are warranted which may offer alternative therapeutic options for chronic wound management.

\section{References}

1. McCarthy MI (2010) Genomics, type 2 diabetes, and obesity. N Engl J Med 363(24): 2339-2350.

2. Guariguata L, Whiting DR, Hambleton I, Beagley J, Linnenkamp U, et al. (2014) Global estimates of diabetes prevalence for 2013 and projections for 2035. Diabetes Res Clin Pract 103(2): 137-149.

3. Andrews KL, Houdek MT, Kiemele LJ (2015) Wound management of chronic diabetic foot ulcers: from the basics to regenerative medicine. Prosthet Orthot Int 39(1): 29-39.

4. Frykberg RG, Banks J (2015) Challenges in the treatment of chronic wounds. Advances in wound care 4(9): 560-582.

5. Sabino F, Keller U (2015) Matrix metalloproteinases in impaired wound healing. Journal of Metalloproteinases in Medicine 2: 1-8.
6. Francis Goforth KN, Harken AH, Saba JD (2010) Normalization of diabetic wound healing. Surgery 147(3): 446-449.

7. Dyer DG, Dunn JA, Thorpe SR, Bailie KE, Lyons TJ, et al. (1993) Accumulation of Maillard reaction products in skin collagen in diabetes and aging. J Clin Invest 91(6): 2463-2469.

8. Lyons TJ, Jenkins AJ (1997) Glycation, oxidation, and lipoxidation in the development of the complications of diabetes: a carbonyl stress hypothesis. Diabetes Rev (Alex) 5(4): 365-391.

9. Goodson SJ (2013) An investigation into effects of in vitro glycation on type I collagen fibrillar structure and related biochemistry. Cardiff University, UK.

10. Tecilazich F, Dinh TL, Veves A (2013) Emerging drugs for the treatment of diabetic ulcers. Expert Opin Emerg Drugs 18(2): 207-217.

11. Rashidi MK, Mirazi N, Hosseini A (2016) Effect of topical mixture of honey, royal jelly and olive oil-propolis extract on skin wound healing in diabetic rats. Wound Medicine 12: 6-9.

12. Stewart JA, McGrane OL, Wedmore IS (2014) Wound care in the wilderness: is there evidence for honey? Wilderness Environ Med 25(1): 103-110.

\section{Your next submission with Juniper Publishers} will reach you the below assets

- Quality Editorial service

- Swift Peer Review

- Reprints availability

- E-prints Service

- Manuscript Podcast for convenient understanding

- Global attainment for your research

- Manuscript accessibility in different formats

( Pdf, E-pub, Full Text, Audio)

- Unceasing customer service

Track the below URL for one-step submission https://juniperpublishers.com/online-submission.php 